\title{
CORTISOL, STRESS AND ADAPTATION DURING EXERCISE TRAINING
}

\author{
Antony C. Hackney, Claudio Battaglini, Elizabeth S. Evans \\ University of North Carolina, USA
}

\begin{abstract}
Anthony C. Hackney. PhD in Biomedical Sciences. Director of Applied Physiology Laboratory, Department of Exercise and Sport Science, Department of Nutrition, School of Public Health, University of North Carolina, USA. Research interests — adaptation of endocrine system to physical loads.
\end{abstract}

\begin{abstract}
Cortisol is a corticosteroid hormone produced by the zona fasciculata of the adrenal cortex in the adrenal gland. It plays vital roles in the body's defense mechanisms when dealing with stress, as well as being important in blood glucose regulation. Regrettably, misconceptions regarding the actions of this hormone have been created around the sports and exercise arena. For example, cortisol most often is viewed as having a counter-productive role in exercise that can lead to a mal-adaptation to the exercise training process, due to the catabolic nature of this hormone with respect to protein turnover. Therefore, the intent of this article is to present an overview and to offer commentary on the necessary and critically important functions of cortisol during exercise, and in the adaptation process associated with exercise training. This is being done to specifically correct several of the misconceptions and misunderstandings that are portrayed within some literature (in particular on the Internet) regarding endocrine responses to exercise and exercise training.
\end{abstract}

Keywords: Endocrine, hormones, glucocorticoids, sports.

\section{INTRODUCTION}

$\mathrm{S}$ tress has been a topic of study for over 100 years. It is well accepted that the paramount early leader in such study was Hans Selye. Classic observations and studies by Selye during the early part of the last century lead to the development of the "General Adaptation Syndrome" theory of stress response (Selye, 1950). This theory proposes an intimate involvement of the adrenal gland, specifically the cortex, in the adaptation and mal-adaptation process to all forms of stress. Exercise and the exercise training process are classified as a stress to the human body (Hackney, 2006). Specifically, for sedentary individuals, exercise is a distress (negative), but as the body accommodates and adapts, exercise transitions to a eustress (positive) (Selye, 1950; Viru, 1976; Hackney, 2006). Selye viewed the adrenal cortex response (i. e., in humans the primary adrenal cortex hormone is the glucocorticoid cortisol) as critical to the positive adaptation to stress. Regrettably, in recent years some researchers in the exercise sciences, as well as some sports enthusiasts, have proposed that cortisol has a counter-productive role in exercise and can lead to a mal-adaptation to the exercise training process, due to the catabolic nature of this hormone with respect to protein turnover (Dohm, 1986). Most certainly cortisol has catabolic actions in the human body; however, in many respects these actions can be beneficial and productive in the response to the stress of exercise 
and exercise training (Viru A., Viru M., 2004). The view by some exercise specialists that increases in cortisol can lead to a predominance of catabolism in the body which results in undesirable aspects within the adaptation of athletes in sports training is an over-simplification of the hormonal rolesactions of cortisol. This simplified and incomplete notion regarding the role-action of cortisol during exercise training has even resulted in the development of nutritional-pharmaceutical supplements and dietary strategies which attempt to suppress cortisol levels at rest and in response to exercise (Duclos et al., 2007; Viru A., Viru M, 2001, 2004). Such actions may in fact actually compromise the ability of select physiological systems to respond and adapt to the stress of exercise.

A. Viru and M. Viru (2004) report that this misconception of the role of cortisol seems rooted in the research focusing upon the testosterone/ cortisol ratio and how it changes in response to exercise training. In the $1980 \mathrm{~s}$, Adlercreutz and associates were the first to focus attention on the testosterone/cortisol ratio, proposing its use as an indication of excessive stress in athletes during their training (Adlercreutz et al., 1986). These authors actually suggested the use of the ratio based upon free testosterone, not total testosterone, to cortisol. This latter fact seems to have been lost to some researchers who have calculated the ratio using the alternative testosterone value (Kuipers, Keizer, 1988; Viru A., Viru M., 2001, 2004). Adlercreutz proposed that a free testosterone/cortisol ratio relative decrease of more than $30 \%$ (or an absolute decrease to the $0.35 \cdot 10^{-3}$ level or below) would be critical. Changes of this magnitude were projected as reflective of an extreme imbalance in the anabolic (represented hormonally by testosterone levels) and catabolic status of the body due to an excessive stress level from exercise training. Interestingly, Adlercreutz et al. were studying "overreaching training", and not "overtraining" per se but the use of the ratio has been extensively applied with respect to the latter form. For an excellent discussion on the distinction between overreaching training and overtraining, the reader is directed to the review article by H. Kuipers and H. A. Kiezer (1988).

The intent of this article is to present an overview and to offer commentary on the necessary and critically important functions of cortisol in exercise, and in the adaptation process associated with exercise training. This is being done to specifically correct several of the misconceptions and misunderstandings that are portrayed within some literature (in particular on the Internet) regarding endocrine responses to exercise and exercise training. For the purpose of organization, this manuscript has been structured into four sections: (a) explanation of the physiological actions of cortisol; (b) brief overview of the cortisol response during exercise; (c) essential aspects of the cortisol response to exercise at rest-recovery, during exercise; and (d) excessive responses and exercise.

\section{PHYSIOLOGICAL ACTIONS OF CORTISOL}

The hormone cortisol is a steroid hormone (IUPAC systematic name; 11, 17, 21-trihydroxy(11-beta)-pregn-4-ene-3, 20-dione [IUPAC website, 2008]) produced by the zona fasciculata of the adrenal cortex in the adrenal gland. It is one of the hormones that are referred to as a glucocorticoid. In humans the other glucocorticoid produced is corticosterone, which is relatively weak in its actions. The name glucocorticoid derives from early research interpretations that these hormones were involved primarily with glucose metabolism. Cortisol plays such a role physiologically by stimulating several processes that are instrumental to increasing and / or maintaining blood glucose (i. e., euglycemia) (Bender, 1993; Brooks et al., 2005; Tortora, Derrickson, 2006). These processes include:

- Stimulation of gluconeogenesis particularly in hepatic tissue. This pathway results in the synthesis of glucose from non-carbohydrate substrates such as amino acids and glycerol from triglyceride breakdown.

- Enhancing the expression of enzymes involved in the gluconeogenesis pathway is a key metabolic function of glucocorticoids.

- Mobilization of amino acids from extra-hepatic tissues: These serve as substrates for gluconeogenesis (see later discussion on the free amino acid pool).

- Inhibition of glucose uptake in muscle and adipocytes as a glucose and glycogen sparing action.

- Stimulation of lipolysis in adipocytes. The hydrolysis of triglycerides and the resulting fatty acid release provide substrate for the production of energy via the Beta-oxidation pathway in tissues like muscle. Again, this provides a means by which to reduce and spare glucose utilization. 
Glucocorticoids are also known to be potent anti-inflammatory and immunosuppressive agents. These actions, however, are typically far more robust in effect when glucocorticoids are administered at pharmacological dosage levels, as opposed to the levels seen in the normal physiologic range (Tortora, Derrickson, 2006). As a consequence, glucocorticoids are widely used as drugs to treat inflammatory conditions such as arthritis and dermatitis, and as an adjuvant therapy for autoimmune diseases. Excessive glucocorticoid levels resulting from either endogenous or exogenous sources have effects on many physiological systems; including inhibition of bone formation, suppression of calcium absorption, delayed wound healing, muscle weakness, increased risk of infection, and negative psycho-neurological impacts (Tortora, Derrickson, 2006; Duclos et al., 2007).

The regulation of cortisol (and other glucocorticoid) levels in the blood involves a straight-forward negative feedback-based system. In response to a stimulus (e.g., stress, such as hypoglycemia), the hypothalamus secretes corticotropin releasing hormone (CRH). In turn, $\mathrm{CRH}$ stimulates the release of adrenocorticotropic hormone (ACTH) from the anterior pituitary, which stimulates the release of cortisol from the adrenal cortex (Tortora, Derrickson, 2006). Elevated circulating cortisol levels signal the anterior pituitary to decrease ACTH secretion. Conversely, increased levels of ACTH and/or cortisol can also signal the hypothalamus to decrease CRH secretion. This interconnected feedback loop of regulation is referred to as the hypothalamic-pituitary-adrenocortical (HPA) axis and is illustrated in Figure 1. Additionally, cytokine agents such as interleukin-6 (IL-6) have been linked to stimulating HPA responses and promoting increases in circulating cortisol (Ostrowski et al., 1999; Steensberg et al., 2003); this seems especially the case for IL-6 emanating from skeletal muscle (Ostrowski et al., 1999; Steensberg et al., 2003; Viru A., Viru M., 2004).

Brief Overview of the Cortisol Response to Exercise. The intent of this section is to provide only a brief overview and summary of the cortisol responses to exercise. For a more in-depth discussion of this topic the reader is directed to references M. Kjaer (1992) and R. G. McMurray and A. C. Hackney (2000).

During short-term exercise such as an incremental maximal oxygen uptake $\left(\mathrm{VO}_{2 \max }\right)$ test, the blood level of cortisol increases in proportion to exercise intensity once the workload is above a critical threshold $\left(50-60 \% \mathrm{VO}_{2 \max }\right.$ ) (Viru, 1992; McMurray, Hackney, 2000). This threshold intensity does however increase slightly as an individual becomes more exercise trained. Thus at the same absolute exercise intensity, the cortisol response may be lower following an exercise training program. During supra-maximal exercise, the cortisol response can be extremely pronounced, but this increase may not be displayed until recovery from the activity, due to the short duration of such activity (Viru, 1976; Kjaer, 1992; Hackney, 2006). During sub-maximal exercise, cortisol responses are more variable and are influenced by several external factors. If the sub-maximal exercise is below the critical threshold intensity then cortisol levels may not increase above resting levels, or they may actually become reduced (Hill et al., 2008). If such low intensity exercise is prolonged enough in duration, levels may gradually increase over time above resting values. If the sub-maximal exercise is above the critical threshold intensity, then cortisol levels will initially increase and subsequently plateau, provided the exercise is steady-state (Viru, 1992; McMurray, Hackney, 2000; Viru et al., 2001). The level of the plateau is proportional to the intensity of the exercise conducted, but if the exercise is prolonged enough in duration, hormone levels will gradually begin to increase again over time (Viru, 1976; Viru et

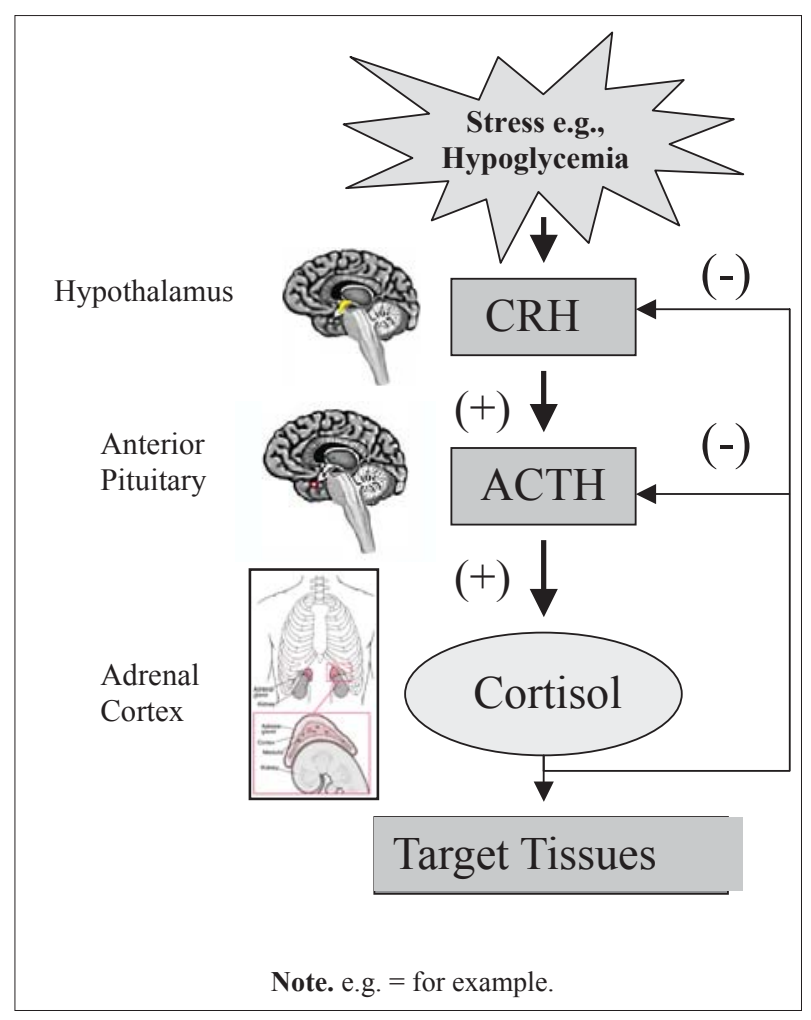

Figure 1. Hypothalamic-pituitary-adrenal (HPA) axis responsible for regulating the levels of cortisol in the blood 
al., 1994). Consumption of a low carbohydrate diet for several days can augment the subsequent cortisol response to sub-maximal exercise (Galbo, 1983; Kjaer, 1992). Furthermore, ambient environmental temperatures can dramatically influence the cortisol response to sub-maximal exercise. Extremely hot or cold temperatures can augment the cortisol response to an exercise session (Galbo, 1983; McMurray, Hackney, 2000). Finally the more exercise trained a person, typically the more blunted the cortisol response to nearly any level of sub-maximal exercise condition (Viru, 1976; Viru, 1992; Viru et al., 2001).

\section{ESSENTIAL ASPECTS OF THE CORTISOL RESPONSE TO EXERCISE}

\section{At Rest and during Recovery from Exerci-}

se. The background information above on the physiologic actions of cortisol illustrate when released in normal amounts, cortisol (like other glucocorticoid agents) has widespread actions which help restore homeostasis of the body after exposure to a stress such as exercise. Most certainly the metabolic influence of cortisol does involve activation of catabolic processes and anti-anabolic actions at the cellular level in many tissues of the body (Bender, 1993). However, these actions are critical to the promotion of protein synthesis which is necessary for the adaptation process in response to a stressful situation (Dohm, 1986; Bender, 1993; Viru et al., 1994; Brooks et al., 2005). For example, these actions lead to a significant increase in the free amino acid pool. Damaged or disrupted protein structures are degraded and their constituent amino acids are placed in the fluids of cells and tissues (Dohm, 1986; Booth, Thomasson, 1991; Brooks et al., 2005). These free amino acids are available as recyclable components or "building blocks" for the synthesis of new proteins, and an expansion of the pool advances this action. Cellular control of protein synthesis essentially occurs at three levels; pre-translation (transcription), translation, and post-translation (Booth, Thomasson, 1991; Tortora, Derrickson, 2006). The impact of cortisol upon the free amino acid pool is influential at the translation level, which consists of constructing and adjusting the number of protein molecules necessary to the need or demand of cells (Booth, Thomasson, 1991; Bender, 1993). Such actions and influences in combination with anabolic endocrine agents can result in enhanced enzymatic and structural proteins in a variety of tissues; i. e., an adaptation response, in which a prime target is skeletal muscle tissue. The ability of the human body to undergo an adaptation in shape, size or characteristic when subjected to a stress exceeding a particular prior "normal" level is referred to as the property of "plasticity" (Brooks et al., 2005). Table summarizes and illustrates aspects of the body's ability to perform a remarkable degree of plasticity in response to exercise training - this is especially true within skeletal muscle tissue (i. e., myo-plasticity). Figure 2 is a schematic illustration representative of the proposed model for factors that influence the myo-plasticity in human skeletal muscle (Brooks et al., 2005). The hormonal inter-play of such endocrine factors as glucocorticoids (cortisol) and anabolic hormones (insulin, testosterone, and insulin-like growth factor 1) are critical and necessary to bring about and maximize the myo-plasticity response in skeletal muscle in response to exercise training (Sheffield-Moore, Urban, 2004).

II. During Exercise. The increases in cortisol seen during exercise are critical to the control and regulation of energy metabolism and thus exercise performance capacity (Viru, 1976; Viru, 1992; Viru et al., 1994; Viru A., Viru M., 2004). This point is well documented in human studies, but is eloquently illustrated in animal-based studies where cortisol responses can be either mitigated through removal of the adrenal gland, or modulated through pharmaceutical implants (it is important to note the principal and most potent glucocorticoid in rodents is corticosterone). For

Table. Examples of select, critical physiological changes occurring with exercise training (see Brooks et al., 2005)

$\uparrow$ Glycolytic enzyme activity within skeletal muscle

$\uparrow$ Oxidative enzyme activity within skeletal muscle

$\uparrow$ Mitochondria density within skeletal muscle

$\uparrow$ Skeletal muscle fiber cross-sectional area

$\uparrow$ Anabolic hormonal receptors number

$\uparrow$ Hormonal receptor sensitivity

$\uparrow$ Maximal oxygen uptake capacity

$\uparrow$ Cardiac Output

$\uparrow$ Stroke Volume

$\uparrow$ Skeletal Muscle strength capacity

$\uparrow$ Skeletal Muscle endurance capacity

$\downarrow$ Depot body fat stores

Note. $\uparrow$ - denotes increase; $\downarrow-$ denotes decrease. 
Figure 2. Schematic representation of the plasticity model of adaptation and the critical components which influence skeletal muscle myo-plasticity (modified from Brooks et al., 2005)

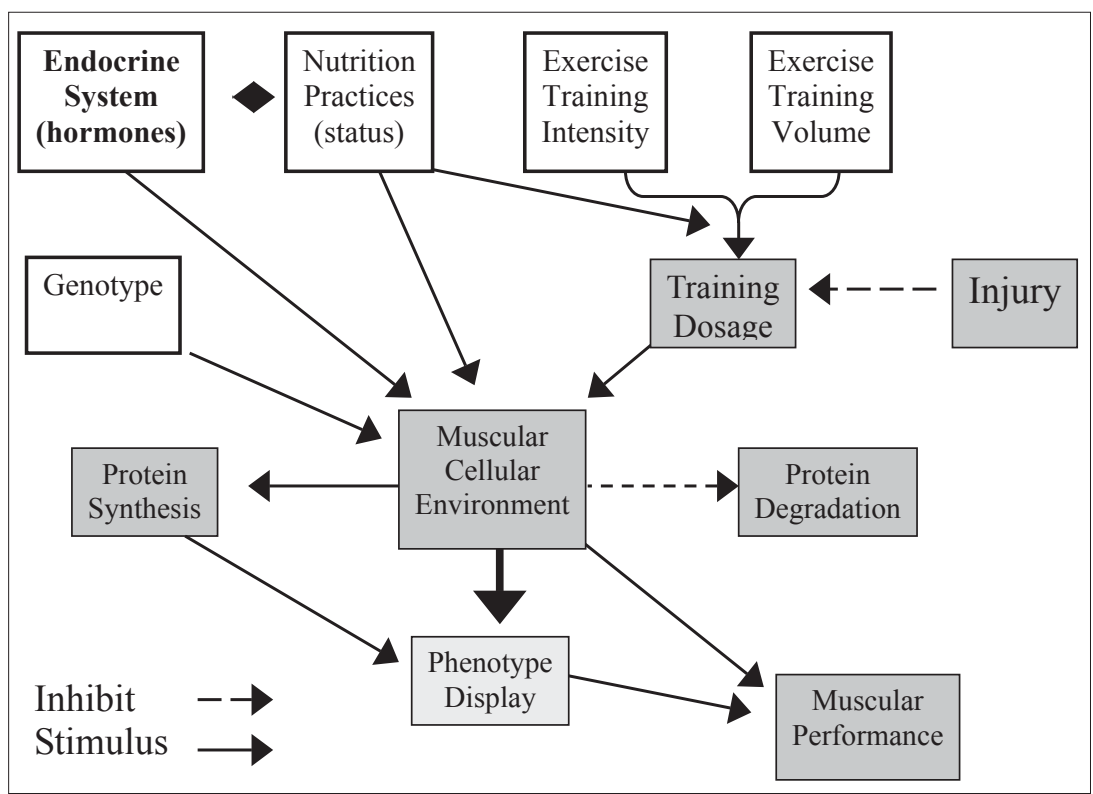

example, T. L. Sellers et al. (1988) demonstrated in adrenalectomized rats that the absence of a glucocorticoid response during prolonged exercise resulted in a more rapid onset of fatigue and muscular exhaustion. During exercise, such adrenalectomized rats also displayed suppressed muscle and hepatic alanine-aminotransferase activity (a key enzyme in protein metabolism function) as well as reduced urea production and elimination (Viru, Eller, 1976; Viru et al., 1994). Furthermore, due to an overall decrease in hepatic gluconeogenic capacity, glucose output is reduced in such animals, thus leading to hypoglycemia during exercise, which is a potent cause of fatigue (Gorski et al., 1987). Duclos et al. eloquently demonstrated that by modifying glucocorticoid levels in rats (i.e., implants), there was a direct and positive dose response effect upon prolonged exercise capacity (Duclos et al., 2007).

An important role of glucocorticoids is the induction of the enzymes associated with catecholamine production, principally the synthesis of phenyl-ethanolamine-N-methyl transferase. This enzyme catalyzes the methylation of norepinephrine to epinephrine (Pohorecky, Wurtman, 1971). Animal research supports that the absence of a glucocorticoid response during exercise results in suppressed catecholamine levels throughout exercise which causes a compromised regulation of several critical physiologic systems (Matlina et al., 1978). There also appears to be a reciprocal effect between the catecholamine and cortisol interactions. Evidence demonstrates that by blocking the actions of the catecholamines (adrenergic receptor blockage), there is suppression of cortisol release
(Pohorecky, Wurtman, 1971). Viru and associates showed such blockage in humans suppresses the cortisol response to strenuous exercise, significantly compromising exercise performance (Viru et al., 2007).

Besides direct actions, glucocorticoids can exert permissive and supportive effects on some metabolic events occurring during exercise. For example, glucocorticoids appear to influence the calcium fluxes in cells and can have inhibitory action on the synthesis of cAMP-phosphodiesterase (Viru A., Viru M., 2004). These actions in-turn promote a greater metabolic action for epinephrine, leading to and accentuating the fatty acid release from adipocytes and accelerating lipolysis during exercise (Malig et al., 1966; Struck, Tipton, 1974; Gorski et al., 1987; McMurray, Hackney, 2005). Additionally during exercise, $\mathrm{Na}+, \mathrm{K}+$ pump enzyme (ATPase) activity is increased in the sarcolemma of muscle; i. e., allowing increased rates of membrane depolarization-repolarization (Clausen, 1986). The elevations in cortisol levels during exercise promotes epinephrine formation, thus activating $\mathrm{Na}^{+}, \mathrm{K}+$ pumps (see above) (Korge, Roosson, 1975; Clausen, 1986).

Even though the catabolic actions of cortisol lead to an expanded free amino acid pool, evidence suggest that enhanced contractile activity such as in exercise may actually defend muscle tissue from an exaggerated level of catabolism and spare some skeletal proteins from degradation (Hickson, Davis, 1981; Seene, Viru, 1982; Dohm, 1986; Varrick et al., 1992). Furthermore, R. C. Hickson et al. (1984) demonstrated that during exercise training, the affinity of muscle 
androgen receptors for glucocorticoids decreases. This in turn allows testosterone to facilitate receptor action and thus reduces glucocorticoid catabolic action. It is important to note that at the receptor level, a competition can exist between structurally alike hormones (such as testosterone and cortisol) for binding sites on receptors. The competition between cortisol and testosterone for glucocorticoid-binding sites is a determinant of the anti-catabolic action of testosterone and the anti-anabolic action of cortisol (Mayer, Rosen, 1977).

III. Excessive Responses and Exercise. Most certainly cortisol and the other glucocorticoids have deleterious effects on the body when excessive levels are reached (Hickson, Davis, 1981; Tortora, Derrickson, 2006). Some of the greatest elevations of cortisol are seen in the medical condition known as Cushing's Syndrome (Daly, Hackney, 2005; Tortora, Derrickson, 2006). Patients with this condition experience many of the health problems (negative physiological changes) mentioned earlier which are promoted by excessive levels of cortisol. Some individuals have speculated that exercise results in a hypercortisolemic state, either as a transient occurrence due to acute exercise or chronically due to overtraining, and this state can induce some of these deleterious physiological effects in athletes (Viru A., Viru M., 2004). However, M. Duclos et al. (2007) noted in a recent review article that there is no evidence to support such claims in normally trained or even overtrained athletes. Furthermore, W. Daly and A. C. Hackney (2005) compared the levels of cortisol in response to intensive prolonged exercise to those found in Cushing's Syndrome patients. The levels in the Cushing's patients far exceeded any of those found in the individuals who exercised. Even patients with anxiety disorders or excessive psychological stress are found to have cortisol levels that typically exceed those found in response to exercise (Boa et al., 2008). Additionally, A. C. Hackney and A. Viru (1999) as well as W. Kern et al. (1995) have demonstrated that in response to transient elevations in cortisol during daytime exercise, there is a substantial and persistent nocturnal suppression in the hormone levels.

\section{CONCLUSIONS}

Glucocorticoids, specifically cortisol, are considered stress response hormones, which in an overly simplified view, are often portrayed as being entirely negative in their influence on physiological function. The glucocorticoids are in fact vital hormones in the normal physiological functioning of humans and are necessary in dealing with different stress challenges to the body. With respect to exercise, they play an important regulatory role in metabolic responses. Additionally, the regulation of protein turnover during the recovery from exercise, which is instrumental to the myo-plasticity response of skeletal muscle in training, is dependent upon appropriate glucocorticoid actions. In other words, cortisol and the other glucocorticoids are not the "bad guys" of exercise endocrinology as some have made them out to be. Researchers, athletes and sports coaches need to be aware and conscious of the critical nature of glucocorticoids to normal health and development, especially relative to exercise training adaptations.

Acknowledgements. Author ACH would like to dedicate this article to Professor Dr. Atko Viru of Tartu University who was a wonderful colleague and friend. Lamentably, Dr. Viru died in the fall of 2007. He will be greatly missed.

\section{REFERENCES}

Adlercreutz, H., Harkonen, K., Kuoppasalmi, K. et al. (1986). Effects of training on plasma anabolic and catabolic steroid hormones and their responses during physical exercise. International Journal of Sports Medicine, 7, 27-28.

Bender, D. A. (1993). Introduction to Nutrition and Metabolism. London: University College London Press.

Boa, A. M., Meynen, G., Swaab, D. F. (2008). The stress system in depression and neurodegenerative focus on the human hypothalamus. Brain Research Reviews, 57 (2), $531-553$.

Booth, F. W., Thomasson, D. B. (1991). Molecular and cellular adaptations of muscle in responses to exercise: Perspectives of various models. Physiological Reviews, $71,541-585$.

Brooks, G. A., Fahey, T. D., Baldwin, K. M. (2005). Exercise Physiology: Human Bioenergetics and Its Applications. Columbus: McGraw-Hill Publishing.

Clausen, T. (1986). Regulation of active $\mathrm{Na}+, \mathrm{K}+$ transport in skeletal muscle. Physiological Reviews, 66, 542-580.

Daly, W., Hackney, A. C. (2005). Is exercise cortisol response of endurance athletes similar to levels of Cushing's Syndrome? Biology and Sport, 22 (3), 209-214. 
Dohm, G. L. (1986). Protein as a fuel for endurance exercise. Exercise and Sport Sciences Reviews, 14, 143-173.

Duclos, M., Guinot, M., LeBouc, Y. (2007). Cortisol and growth hormone: Odd and controversial ideas. Applied Physiology, Nutrition and Metabolism, 32, 895-903.

Galbo, H. (1983). Hormonal and Metabolic Adaptation to Exercise. New York: Georg Thieme Verlag.

Gorski, J., Nowacka, M., Namiot, Z., Kiryluk, T. (1987). Effect of exercise on energy substrate metabolism in tissues of adrenalectomized rats. Acta Physiologica Polonica, 38, $331-337$.

Hackney, A. C. (2006). Stress and the neuroendocrine system: The role of exercise as a stressor and modifier of stress. Expert Review of Endocrinology and Metabolism, 1 (6), 783-792.

Hackney, A. C., Viru, A. (1999). Twenty-four cortisol response to multiple daily exercise sessions of moderate and high intensity. Clinical Physiology, 19, 178-182.

Hickson, R. S., Davis, J. R. (1981). Partial prevention of glucocorticoid-induced muscle atrophy by endurance training. American Journal of Physiology, 241, E 226-232.

Hickson, R. C., Kurkowski, T. T., Capaccio, J. A., Chatterton, R. T. (1984). Androgen cytosol binding in exerciseinduced spring of muscle atrophy. American Journal of Physiology, 247, E 597-603.

Hill, E. E., Zack, E., Battaglini, C. et al. (2008). Exercise and circulating cortisol levels: The intensity threshold effect. Journal of Endocrinological Investigation (in press).

IUPAC - International Union of Pure and Applied Chemistry. Internet link: http://www.iupac.org/, accessed 2008.

Kern, W., Perras, B., Wodick, R., Fehm, H. L., Born, J. (1995). Hormonal secretion during nighttime sleep indicating stress of daytime exercise. Journal of Applied Physiology, 79 (5), 1461-1468.

Kjaer, M. (1992). Regulation of hormonal and metabolic responses during exercise in humans. Exercise and Sport Sciences Reviews, 20, 161-184.

Korge, P., Roosson, S. (1975). The importance of adrenal glands in the improved adaptation of trained animals to physical exertion. Endokrinologie, 64, 232-238.

Kuipers, H., Keizer, H. A. (1988). Overtraining in elite athletes: review and directions for the future. Sports Medicine, 6, 79-92.

Malig, H., Stern, D., Atland, P., Highman, B., Brodie, B. (1966). The physiological role of the sympathetic system in exercise. The Journal of Pharmacology and Experimental Therapeutics, 154, 35-45.

Matlina, E., Schreiberg, G., Voinova, M., Dunajeva, L. (1978). The interrelationship between catecholamines and corticosteroids in the course of muscular fatigue. Sechenov Physiological Journal of the USSR, 64, 171-176.

Mayer, M., Rosen, R. (1977). Interaction of glucocorticoids and androgens with skeletal muscle. Metabolism, 96, 937-962.

McMurray, R. G., Hackney, A. C. (2000). The endocrine system and exercise. In: W. Garrett (Ed.), Exercise \& Sports Science. Philadelphia: Williams \& Wilkins Publisher. P. $135-162$.

McMurray, R. G., Hackney, A. C. (2005). Interactions of metabolic hormones, adipose tissue and exercise. Sports Medicine, 35 (5), 393—412.

Ostrowski, K., Rohde, T., Asp, S., Schjerling, P.,
Pedersen, B. K. (1999). Pro- and anti-inflammatory cytokine balance in strenuous exercise in humans. Journal of Physiology, 15, 287-291.

Pohorecky, L. A., Wurtman, R. J. (1971). Adrenocortical control of epinephrine synthesis. Pharmacological Reviews, 23, 1-35.

Seene, T., Viru, A. (1982). The catabolic effects of glucocorticoids on different types of skeletal muscle fibers and its dependency upon muscle activity and interaction with anabolic steroids. Journal of Steroid Biochemistry, 16, $349-352$.

Sellers, T. L., Jaussi, A. W., Yang, H. T., Heninger, R. W., Winder, W. W. (1988). Effect of exercise-induced increase in glucocorticoids on endurance in the rat. Journal of Applied Physiology, 65, 173-178.

Selye, H. (1950). The Physiology and Pathology of Exposure to Stress. Montreal: Medical Publishers.

Sheffield-Moore, M., Urban, R. J. (2004). An overview of the endocrinology of skeletal muscle. Trends in Endocrinology and Metabolism, 15 (3), 110-115.

Steensberg, A., Fischer, C. P., Keller, C., Moller, K., Pedersen, B. K. (2003). IL-6 enhances plasma IL-1ra, IL-10, and cortisol in humans. American Journal of Physiology, 285, E 433-437.

Struck, P. J., Tipton, S. M. (1974). Effect of acute exercise on glycoge levels in adrenalectomized rats. Endocrinology, 95, 1385-1391.

Tortora, G. J., Derrickson, B. (2006). Principles of Anatomy and Physiology $11^{\text {th }}$ Edition. Hoboken: Wiley \& Son.

Varrik, E., Viru, A., Oopik, V., Viru, M. (1992). Exerciseinduced catabolic responses in various muscle fibers. Canadian Journal of Sports Science, 17, 125-128.

Viru, A., Eller, A. (1976). Adrenal cortical regulation of protein metabolism during prolonged exertion. Biulleten Eksperimentalnoi Biologii i Meditsiny, 82, 1436-1439.

Viru, A., Hackney, A. C., Valja, E., Karelson, K., Janson, T., Viru, M. (2001). Influence of prolonged continuous exercise on hormone responses to subsequent exercise in humans. European Journal of Applied Physiology, 85, 578 - 585.

Viru, A., Litvinova, L., Viru, M., Smirnova, T. (1994). Glucocorticoid in metabolic control during exercise: Alanine metabolism. Journal of Applied Physiology, 76, $801-805$.

Viru, A. (1992). Plasma hormones and physical exercise. International Journal of Sports Medicine, 13, 201-209.

Viru, A. (1976). The role of adrenocortical response to physical stress on the body's work capacity. Biulleten Eksperimentalnoi Biologii i Meditsiny, 82 (7), 774-776.

Viru, A., Viru, M. (2001). Biochemical Monitoring of Sports Training. Human Kinetics, Champaign.

Viru, A., Viru, M. (2004). Cortisol - essential adaptation hormone in exercise. International Journal of Sports Medicine, 25, 461-464.

Viru, A., Viru, M., Karelson, K. et al. (2007). Adrenergic effects on adrenocortical cortisol response to incremental exercise to exhaustion. European Journal of Applied Physiology, 100 (2), 241-245.

Viru, M., Litvinova, L., Smirnova, A., Viru, A. (1994). Glucocorticoids and metabolic control during exercise: Glycogen metabolism. Journal of Sports Medicine and Physical Fitness, 34, 377-382. 


\title{
KORTIZOLIS, STRESAS IR ORGANIZMO ADAPTACIJA PER TRENIRUOTES
}

\author{
Antony C. Hackney, Claudio Battaglini, Elizabeth S. Evans \\ Šiaurès Karolinos universitetas, JAV
}

\begin{abstract}
SANTRAUKA
Kortizolis yra kortisteroidinis hormonas, kuri gamina antinksčiu žievės zona fasciculata (pluoštinė zona) antinksčių liaukoje. Jis atlieka gyvybiškai svarbią mechanizmų gynybinę funkciją tada, kai tenka ivveikti stresą, taip pat jis reguliuoja gliukozès kieki kraujyje. Labai gaila, bet sporto srityje šio hormono veikla yra klaidingai suprantama. Pavyzdžiui, dažnai manoma, kad kortizolis neigiamai veikia mankštinantis, ir dèl šio hormono katabolinès prigimties, turint omeny baltymų kaitą, per treniruotes organizmas sunkiai adaptuojasi. Šio straipsnio tikslas - apžvelgti ir išsiaiškinti, kokias nepaprastai svarbias funkcijas kortizolis atlieka per treniruotes ir adaptacijos metu, taip pat bandyta paneigti keleta konkrečių klaidingų sampratų ir nuomonių, pateikiamų kai kuriuose literatūros šaltiniuose (ypač internete) apie endokrinines organizmo reakcijas treniruojantis.
\end{abstract}

Raktažodžiai: hormonai, gliukokortikosteroidai, sportas.

Gauta 2008 m. liepos 28 d.

Received on July 28, 2008 